NAGYILLÉS JÁNOS

\title{
Anna Maria van Schurman: Értekezés arról, hogy illik-e egy keresztény nőhöz a tudományok tanulmányozása? ${ }^{1}$
}

Nincs még négyszáz éve, hogy Anna Maria van Schurman személyében először ülhetett női hallgató egy egyetemi auditórium padsoraiba Utrechtben. Az olvasó e mindössze huszonöt éves hölgy értekezését tartja kezében. A rövid munka sajátságos és meglehetősen visszafogott reflexió az ókori és későbbi, már keresztény hagyományban gyakran megjelenő hangokra, melyek szerint a nők vagy alkalmatlanok komoly szellemi munkára, vagy ha alkalmasak, nem tanácsos ilyesmivel foglalkozniuk. Éppen ezért a szerző a legkomolyabb tekintélyek, többek között Platónt, Arisztotelész és Nagy Szent Gergely tanúságait mozgósítja, amelyeket az érvelés évszázadok során kikristályosodott módszertanán alapuló érvrendszerbe illeszt. Nemcsak a kérdésfelvetés mellett, hanem az ellene szóló érveket is áttekinti. A rövid opusz van Schurman legismertebb müve lett. André Rivet teológusnak hozzá intézett levelében 1632-ben mutatta be, majd 1638-ban Párizsban, 1641-ben pedig Leidenben is publikálta. A magyar fordítás a leideni kiadás alapján készült, ${ }^{2}$ mely Rivet válaszát és megjegyzéseit is tartalmazza, ezt hamarosan szintén közzétesszük magyar fordításban.

\footnotetext{
${ }^{1}$ A publikáció az MTA-SZTE Antikvitás és Reneszánsz: Források és Recepció Kutatócsoport (TK2016-126) támogatásával jelent meg. A fordítás ellenőrzéséért és értékes javaslataiért, kiegészítéseiért Lázár István kollégámnak mondok köszönetet.

2 Anna Maria van Schurman: Dissertatio de Ingenii Muliebris ad Doctrinam, \& meliores Litteras aptitudine, Lugduni Batavorum, 1641
} 


\section{Anna Maria van Schurman: Értekezés arról, hogy illik-e egy keresztény nőhöz a tudományok tanulmányozása?}

\section{Gyakorlati problémafelvetés:}

illik-e egy keresztény nőhöz a tudományok tanulmányozása?

Igyekszem a mellette szóló érveket szemügyre venni. A következő előismereteket bocsátjuk előre előbb az alany, majd az állítmány vonatkozásában. Az alany szavai teljesen egyértelműek - hiszen ha "keresztény nô"'-ről beszélek, úgy értem, hitvallása szerint is és valójában is az. Az állítmányban szereplő szavak először is "a tudomány tanulmányozása”. „Tanulmányozás"-nak mondom (s a szó más jelentéseire nem térek ki), ahogy itt használjuk, s ez a figyelem szorgalmas és eltökélt odafordítása.

A „tudomány" szón a nyelvek és történelem ismeretét értem, minden tudományt, mind a magasabbakat, melyeket jártasságoknak, mind pedig az alacsonyabbakat, melyeket bölcseleti tudományoknak neveznek. ${ }^{1}$ Kizárólag a bibliai exegézis a kivétel, mert vitán fölül áll, hogy ez minden egyes keresztényhez illik.

Másodszor az illik szó következik - azaz hogy üdvös, hasznos és tisztes.

Az ily módon különválasztott szavaknak kell magukat a témákat is különválasztaniuk. A nók némelyike például tehetséges, némelyik viszont butácska, némelyik szegény, némelyik tehetős, végül némelyik jeleskedik a ház körüli elfoglaltságokban, némelyik meg kevésbé jó bennük. A „tudomány tanulmányozása” kifejezés felosztható vagy általánosakra, amennyiben minden tudománnyal egyaránt foglalkozunk, vagy különösekre, ha valamely jártasság segítségével egy-egy nyelvet vagy tudományágat tanulmányozunk.

\footnotetext{
${ }^{1}$ Van Schurman eredeti szövege itt alighanem felcseréli a két jelzőt (superiores, inferiores): a tudományterületek közül alacsonyabbak a jártasságok (facultates), s magasabbak a bölcseleti tudományok (scientiae philosophicae)
} 


\section{Éppen ezért megkötésekhez folyamodunk ${ }^{2}$}

Először is az alannyal kapcsolatban: az érvelés tárgyát képező nő legyen legalábbis átlagos képességü, aki a tanulmányokra nem teljesen alkalmatlan. Másodszor legyen felruházva a szükséges eszközökkel, s egyáltalán ne akadályozza családja szerény anyagi helyzete. Ezt a kivételt itt azért teszem, mivel csak kevés nőnek jut osztályrészül az a szerencse, hogy olyan szülei legyenek, akik maguk is akár akarják, akár tudják taníttatni lányaikat, az oktatók foglalkoztatása pedig költséges. Harmadszor, hogy a körülményeik és sorsuk nyújtotta feltételek olyanok legyenek, hogy akár általános, akár egyéni hivatásuktól, nem mellesleg a jámborság gyakorlásától, akár családjuk ügyes-bajos dolgaitól legyen olykor szabad idejük. Ez részben gyermekkorban kivitelezhető könnyedén, ez még mentes és szabad a gondoktól és tennivalóktól, részben pedig előrehaladottabb életkorban vagy férj nélkül élve, vagy szolgálónők segítségére támaszkodva, mert ez utóbbiak általában a gyermekes aszszonyokat is fel szokták szabadítani a ház vezetésének teendői alól. Negyedszer, hogy legyen célja - és nem pusztán a hiú dicsőség és kivagyiság vagy valamiféle haszontalan kíváncsiság - éspedig az általános célon kívül is, ami természetesen Isten Dicsősége és saját lelkének üdvössége: mégpedig az, hogy saját maga is minél jobban és szerencsésebben jusson előre, s családját (ha efféle kötelesség hárul rá) oktassa és irányítsa, s amennyire az lehetséges, egész nemének is legyen hasznára.

\section{Az állítmány megkötései}

A „tudomány tanulmányozásá"-nál azzal a megkötéssel élek, hogy megítélésem szerint mindenképpen keresztény nőkhöz illenek a tisztes tudományok, mert ezek az ember sajátos és általános javai és ékességei, a tisztes tudományok, ahogy nevezni szokták őket: általános $\varepsilon \gamma \gamma \kappa v \kappa \lambda$ о $\alpha \iota \delta \varepsilon \dot{\alpha} \alpha$ (ejtsd enkyklopaideia = teljes körű múveltség), mindazonáltal úgy, hogy mindegyik tudomány vagy müvészet méltósága és

\footnotetext{
${ }^{2}$ A bekezdés szövege mellett lapszélen Schurman a következő szöveget közli: Olyan nők oktatásáról, akiket részben külföldi gazdagoknál, részben hazájukban taníttattak, a következő szövegeket érdemes elolvasni: Livius 3. könyve; Plinius Levelei, 1, 17; Athénaios 1. könyve; Plutarchos $A$ nevelésról szóló könyve; Gordianus 15. könyve $A$ tevékenységekról; Fornerius Cassiodorushoz.
} 
természete szerint, valamint magának a lánynak vagy asszonynak tehetségéhez és élethelyzetéhez mérten, egyesével a maga során, helyén és idejében következzék $s$ váltsa a másikat a tanulás során úgy, ahogy alkalmasan hozzá kapcsolódik. Elsősorban azonban azokra a tudományokra vagy múvészetekre kell gondot fordítani, melyek a legközelebbi kapcsolatban állnak a Szent Teológiával és az erkölcsi erényekkel, s kiváltképp szolgálják ezeket. Úgy vélem köztük van a grammatika, logika, retorika, elsősorban azonban a logika, melyet mindenki kifejezetten minden tudomány kulcsának nyilvánít. Utána a fizika, metafizika, történelem és a többi, s szintúgy a nyelvek, különösen a héber és a görög ismerete. Mindezek hozzásegíthetnek bennünket a Szentírás könnyebb és teljesebb megértéséhez, hogy a többi szerzőéről már ne is beszéljek. A többi tudományág, úgymint a matematika (ezzel kapcsolatban van a zene), a költészet és a többi, a festészet és hasonló szabad művészetek ékesség és gyönyörüség gyanánt szolgálhatnak. Végül azon tanulmányokat, amelyek a jogtudomány, a hadtudomány gyakorlatára vonatkoznak, és az egyházi, politikai és akadémiai szónoklás müvészetét, minthogy azok kevésbé jellemzőek és szükségesek, nem szorgalmazzuk túlságosan. Mindemellett semmiképpen nem engedjük meg, hogy a nőket kizárják az ilyesféle dolgok iskolai, vagy elméleti ismeretéből, különösen pedig a legnemesebb politikai tudomány ismeretéből.

Megkötést teszünk azzal az igével kapcsolatban, hogy „illik” vagy üdvös a tudományokkal való foglalkozás, nem azért, mert az jellemző vagy kívánatos, egyszóval az örök üdvösséghez szükséges, mégpedig nem mint olyan javunkat, ami az evilági élet lényegére vonatkozik, hanem mert olyan kötelesség vagy eszköz, mely nagyon nagyban hozzájárulhat az élet teljességéhez, sőt mi több a legszebb tárgyakon való elmélkedés segítségével sokkal könnyebben segíthet hozzá Isten szeretetéhez és az örök üdvösséghez.

Tételünk tehát legyen a következő:

A tudomány tanulmányozása illik a keresztény nőhöz Az alátámasztását szolgáló érveket előbb az alannyal, majd az állítmánnyal kapcsolatban hozom fel. 


\section{Az alany sajátosságából a következő érv származik}

Akibe csak beléplántálta a természet minden müvészet és tudomány csíráit (principia), vagy minden müvészet csíráinak lehetőségét, annak minden müvészet és tudomány való is. A nőkbe pedig a természet beléplántálta minden müvészet és tudomány csíráját, vagy annak lehetőségét. Tehát minden müvészet és tudomány való a nőknek. Az alaptétel bizonyítható, mivel akikhez illenek e csírák vagy azok lehetőségei, annak a belőlük adódó következtetések ismerete is való, mert azok természetük folytán ugyanazokból származnak.

A kiegészítő tétel bizonyítható egyrészt ezen alany vagy az emberi értelem jellegének sajátosságából, másrészt magukból cselekvéseikből vagy hatásukból, már amennyiben nyilvánvaló, hogy a nők cselekvés útján sajátítanak el bármely tudományt vagy müvészetet: márpedig cselekvés senkinek az esetében sem lehetséges annak csírái nélkül.

\section{Az alany sajátosságából származó érv}

Akiben természettől fogva megvan a vágyakozás a tudományok és müvészetek iránt, ahhoz illenek a tudományok és müvészetek, márpedig a nőkben természettől fogva megvan a vágyakozás a tudományok és müvészetek iránt, tehát:

A nagyobbik bizonyítása nyilvánvaló, mivel a Természet nem tesz semmit hiábavalóan.

A kisebbik úgy bizonyítható, hogy ami megvan az egész fajban, megvan az egyes egyedekben is. Márpedig minden ember (ahogyan határozottan állította a Filozófus a Metaphysic. 1. könyvének 2. fejezetében) természettől vágyik a tudásra.

III. A sajátosságból vagy külső hozzákapcsolásból származó érv

Mindenkihez, akit Isten felfelé tekintő, égre emelt arccal teremtett, illik a felfelé irányuló és égi dolgokon való elmélkedés és gondolkodás. Márpedig Isten a nőt felfelé tekintő és az ég felé emelt arccal teremtette, tehát:

$S$ bár más lények meggörnyedve a földre tekintnek, Ég fele tartja az ember az arcát stb. ${ }^{3}$

\footnotetext{
${ }^{3}$ Ov. Met. 1, 84-85. Magyar metrikus fordítása: Minden egyéb állat letekint görnyedten a földre, / embernek fölemelt orcát... Fordította Devecseri Gábor: OvIDIUS (1975: 9).
} 


\section{IV. Érvelés}

Aki a leginkább szorul szilárd és folyamatos elfoglaltságra, annak való leginkább a tudománnyal való foglalkozás. Márpedig a nők szorulnak leginkább szilárd és folyamatos elfoglaltságra, tehát:

A nagyobbik következményének bizonyítása abban áll, hogy semmi sem irányítja egyformán minden lelki mozgását önmagára, és - mint a nagy Erasmus mondja ${ }^{4}$ - semmi sem foglalja el egy leány lelkét olyannyira teljes egészében, mint a tanulmányok, ahová majd bármilyen alkalommal mintegy menedékbe menekülhet.

A kisebb a következő kettős érvvel bizonyítható.

1. Aki szelleme vagy vérmérséklete gyámoltalansága és állhatatlansága s a világ számtalan csábítása miatt a leginkább ki van téve a hívságok veszélyének, az szorul rá leginkább a szilárd és folyamatos elfoglaltságra. Márpedig a nők szellemük és..., tehát:

A nagyobbik rész megint csak bizonyítható: mivel ellentétét legjobban egy ellentét gyógyítja, nincs, ami a hívságos dolgoknak jobban ellenáll, mint az elmélyült és folyamatos elfoglaltság.

Úgy vélem, a kisebbik rész vitán felül áll, mivel a mégoly hősies erényesség is aligha győzheti le a világ és az ifjúság szirénjeit, ha nem foglalják el komoly és szilárd dolgok.

2. Az altételt bizonyító érv, avagy a IV. Érv kisebbik része.

Az szorul rá leginkább a szilárd és folyamatos elfoglaltságra, akinek legtöbb a szabadideje, márpedig azoknak a nőknek a legtöbb a szabadideje, akinek életkörülményei a legjobbak.

A nagyobbik rész következménye megint csak bizonyítható, 1. mivel a szabadidő önmagában is unalommal jár, sőt mi több terhes, úgyhogy méltán mondta az isteni Naziánzi [Szent Gergely], hogy $\mu \varepsilon \gamma i \sigma \tau \eta$

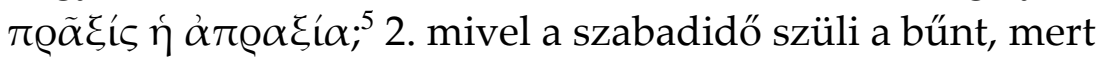

A semmitevés tanítja rossz tettekre az embert. ${ }^{6}$

\footnotetext{
${ }^{4}$ A lapszélen a hely pontosítása: Buddeushoz írt levelében, melyben Morus Tamás leányainak neveléséről értekezik.

${ }^{5}$ Greg. Naz. theol. epist. 49, 1, 4. Magyarul: A legnagyobb cselekvés a cselekvés hiánya.

${ }^{6}$ Walther 11 091a.
} 


\section{V. Érv}

Annak való a tudományok tanulmányozása, akinek nyugodt és szabad élet jutott osztályrészül. Márpedig a nők élete mindenütt nyugodt és szabad, tehát mindenütt való a nőknek a tudomány tanulmányozása.

A nagyobbik részt igazoló érv kézenfekvő, mivel nincs semmi, ami annyira elősegítené a tanulmányokat, mint a nyugalom és szabadság.

A kisebbik részt a következő érvvel bizonyítom: mint az többnyire van, akinek osztályrészül jut, hogy van ideje magára és nem terhelik közéleti gondok és teendők, annak élete nyugodt és szabad, márpedig a nőknek (különösen ha nem élnek házasságban) osztályrésze, hogy van idejük magukra, stb. tehát:

\section{VI. Érv}

Akinek van lehetősége a legjelentősebb tudományok tanulmányozására, annak a segéd- vagy támogató tudományok tanulmányozására is van lehetősége. Márpedig a keresztény nőnek van lehetősége a legjelentősebb tudományok tanulmányozására stb. tehát:

A nagyobbik rész követkeménye is érvényes, mivel

Akinek van lehetősége a célra, annak az ahhoz való eszközök is rendelkezésére állnak, amelyekkel az illető cél eléréséig a legkönnyebben jutnak, márpedig a segéd- vagy támogató tudományok arra való eszközök, stb. tehát:

A kisebbik azzal igazolható, hogy a keresztény nőhöz illenek a tanulmányok, illetve az Isten igéjén való szakadatlan és elmélyült elmélkedés, Isten ismerete s legszebb múveinek szemlélése, minthogy mindezek minden keresztényt egyformán tartoznak.

Annak való a tudományok tanulmányozása, akinek inkább otthon, egyedül, mint a közéletben mások körében kell szórakozást keresnie, márpedig a nőknek inkább otthon, egyedül, mint a közéletben, mások körében stb. tehát:

A nagyobb rész igaz a leginkább, mivel a tanulmányok biztosítják azt a kiváltságot, hogy még ha más kísérőjük nem is akad, mindig gyönyör kíséri őket, ahogy a bölcs a görög mondás szerint bölcsnek az ilyen

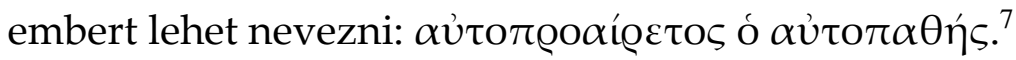

\footnotetext{
${ }^{7}$ Aki magát választja, a maga tapasztalatáról árulkodik. Azonosítatlan eredetű bölcsesség.
} 
A kisebbiket igazoló érv éppily világos: mivel az Apostol előírja, hogy a nőknek oikov@oús-nak (sic!) (ejtsd: oikúrús - helyesen:

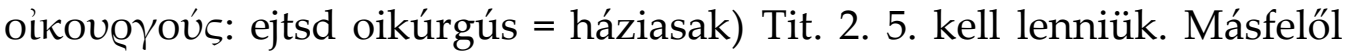
maga a tapasztalat is tanúsítja, hogy a legtöbben azon nők hüségét, ügybuzgalmát, sőt tisztességét vonják kétségbe, akiknek nyelve, füle, szeme gyakran szokott kalandozni és otthonán kívül hajhászni az élvezeteket.

VII. Az állítmány avagy a tudomány jellegén alapuló érvelés Akihez minden erény illik a maga nemében, ahhoz a tudományok és múvészetek is illenek, márpedig a nőkhöz minden erény illik a maga nemében, tehát a nőkhöz a tudományok és müvészetek is illenek.

A nagyobbik rész nyilvánvaló abból, hogy az erény szellemi és erkölcsi erényre osztható, s a Filozófus az előbbi (szellemi )alá sorolja a tudományokat és müvészeteket.

A kisebbik rész nem szorul bizonyításra, amennyiben az erény mint Seneca mondja - sem társadalmi helyzetben, sem nemben nem válogat.

\section{A tudomány célján alapuló érvelés}

Mindaz, ami csak hozzájárul az emberi értelemhez, s ami ékesíti azt, illik a keresztény nőhöz. Márpedig a tudományok és művészetek hozzájárulnak az emberi értelemhez, és díszei annak, tehát:

A nagyobbikat igazoló érv a következő: mivel minden teremtényhez illik önmaga végső és legmagasabb fokú tökéletesítése, minden erőnkkel erre kell törekednünk.

A kisebbik bizonyítása: mivel a tudományok és múvészetek olyan sajátságok, melyek az emberi értelem természetes hatóköréhez (potentiae) tartoznak. ${ }^{8}$

\section{IX. Érv}

Bármi, ami természete szerint hozzájárul, hogy Isten szeretete és tisztelete felébredjen bennünk, illik a keresztény nőhöz. Márpedig a tudományok és művészetek természetüknél fogva hozzájárulnak, hogy Isten szeretete és tisztelete felébredjen bennünk, tehát:

\footnotetext{
${ }^{8}$ A bekezdés mellett lapszéli jegyzetben: Ha a jóhoz jót adnak, mint a Filozófus a Topikában mondja, azt nagyobb jóvá tesszük.
} 
Napnál világosabb, hogy a nagyobbik rész igaz, mivel minden emberhez illik az Isten iránti legtökéletesebb szeretet és legnagyobb tisztelet, úgyhogy ebben senki sem eshet a túlzás hibájába.

A kisebbik a következő érvvel igazolható. Bármi, ami lehetővé teszi, hogy Istent és Isten műveit magasabb fokon szemlélhessük és ismerhessük meg, természeténél fogva hozzájárul, hogy Isten iránt nagyobb szeretet és tiszteletet ébresszen bennünk. Márpedig a tudományok és múvészetek lehetôvé teszik, hogy Isten és Isten múveit magasabb fokon szemlélhessük és ismerhessük meg, tehát:

A nagyobbik megint csak igazolható a következő érveléssel: bármit, ami valóban a legszebb, legjobb és legtökéletesebb, annál inkább kedvelnek, minél inkább megismernek és népszerüségre méltónak tartanak, márpedig Isten és minden múve a legszebb, legjobb stb., tehát:

A kisebbik rész megint csak igazolható a tudományok célja és hatásai alapján, mert ezek között egy sincs, mely ne járulna hozzá a lehető legnagyobb mértékben Isten és Isten művei könnyebb és világosabb megismeréséhez.

\section{X. Érv}

Bármi, ami felvértez bennünket a tévtanok ellen, s leleplezi csalásaikat, illik a keresztény nőhöz, márpedig a tudományok és múvészetek... stb., tehát:

A nagyobbik részt igazoló érv magától értetődik, mivel egyetlen keresztény sem hanyagolhatja el kötelességét e közös veszély kapcsán.

A kisebbik bizonyítása: mivel üdvösebb a filozófia, mint valami páncél és - hogy alexandriai Kelemen szavaival éljek - az Úr szőlősének kerítése, vagy (s ezt a hasonlatot a nagy Vazul alkalmazta) az Evangéliummal összehasonlítva - olyan, mint a levelek, melyek díszítik is, védik is gyümölcseit. Helyes érvelés segítségével persze az általában a tévtanok alapját képező hamis vagy hibás érvelés könnyedén cáfolható.

$$
\text { XI. Érv }
$$

Bármi, ami úgy közvetít tudást, hogy nem károsítja a jóhírt és tisztességet, illik a keresztény nőhöz. Márpedig a tudományok tudást közvetítenek, és nem károsítják a jóhírt... stb., tehát: 
A nagyobb rész általánosan elismert igazság: mivel köztudott, hogy a női nem megbecsülése igen érzékeny jószág, szinte nincs is semmi más, amire jobban rászorulna, mint az okosságra. Aztán meg mennyire nehéz és - ahogy mondani szokás - kockázatos a gyakorlatból és tapasztalatból meríteni az okosságot.

A kisebbik rész is igazolható, mivel a tudós férfiak írásai nem pusztán remek tanításokat tartalmaznak, hanem egyúttal gyönyörü példákkal is szolgálnak nekünk, s mintegy kézen fogva vezetnek bennünket az erényhez.

\section{XII. Érv}

Bármi, ami hozzásegít az igaz lelki nagysághoz, illik a keresztény nőhöz. Márpedig a tudományok tanulmányozása hozzájárul az igaz lelki nagysághoz, tehát:

A nagyobbikat azzal bizonyítom, hogy minél inkább hajlunk saját természetünknél fogva a kicsinylelküség bünére, annál inkább rá vagyunk szorulva az ellentétét jelentő erény támaszára. Márpedig a nő természeténél fogva... stb., tehát:

A kisebbet így lehet bizonyítani: mivel a tudomány fölemeli az emberi lelket, s megfosztja álarcuktól mindazokat a dolgokat, melyektől általában félni szoktak, vagy mértéktelenül vágyakoznak utánuk.

XIII. Érv

Bármi, ami különleges és tisztességes gyönyörrel árasztja el az emberi lelket, illik a keresztény nőhöz. Márpedig a tudomány tanulmányozása különleges és tisztességes gyönyörrel... stb., tehát:

A nagyobbik rész érvének bizonyítása: mivel semmi sem gyökerezik oly mélyen az emberi természetben, mint a különleges és tisztességes gyönyör, ami valamelyes hasonlóságot mutat az emberben Isten örömével, amit nagyszerüen hirdet Arisztotelész 7. Ethica 13. következő szavaival: A gyönyör valamiféle, a természettól emberbe oltott isteni dolog.

A kisebbik bizonyítása a következő: mivel nincs olyan gyönyör (kivéve a keresztények természetfölötti gyönyörét), sem mely méltóbb nemes szellemhez, sem mely annál nagyobb, mely a tudomány tanulmányozásából szokott származni, amit egyrészt példák alapján, másrészt különböző módokon könnyű bebizonyítani. 


\section{Az ellentétből származó érvelés}

Akihez nem illik a tudatlanság és járatlanság, ahhoz illik a tudományok tanulmányozása. Márpedig a keresztény nőhöz nem illik a tudatlanság... stb., tehát:

A nagyobbat a következő érvelés bizonyítja. Bármi, ami önmagában nemcsak az értelemben egy-egy tévedés oka, hanem egy büné is az akaratban vagy cselekvésben, nem illik a keresztény nőhöz. Márpedig a tudatlanság és járatlanság önmagában egy-egy tévedés oka... stb., tehát:

A nagyobbat igazoló érv bizonyítást nyer az elsőben, vagyis amikor az értelemben történő tévedés lehetőségét vesszük figyelembe, mivel a tudatlanság vagy járatlanság az értelemben - amit a lélek szemének is neveznek - nem más, mint vakság és sötétség, ami minden tévedésnek az oka. A másodikban, amikor a bün lehetőségét vesszük figyelembe az akartban vagy a cselekvésben: Mivel önmagában dölyfössé, vaddá stb. teszi az embereket, azaz a bün oka az akaratban vagy a cselekvésben. Márpedig a tudatlanság vagy járatlanság önmagában dölyfössé stb. teszi az embert, tehát: ${ }^{9}$

A nagyobbikkal kapcsolatos érv nyilvánvaló.

A kisebbik bizonyítása: Mivel minél kevésbé ismeri valaki önmagát, annál önhittebb s megvet másokat. És aki nem tudja, mennyi mindent nem tud, jóformán csak magának okos. Azután - hogy folytassam a vadsággal nincs kiállhatatlanabb a tudatlanságnál, amit Erasmus is tanúsít, mert nem egyszer tapasztalta. És hogy az isteni Platón véleményét idézzem e helyen:

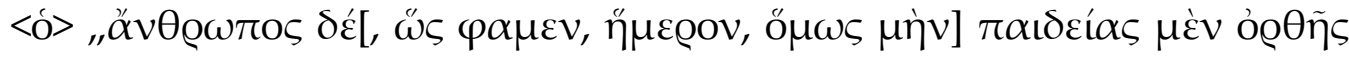

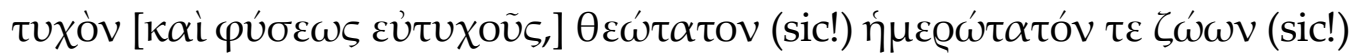

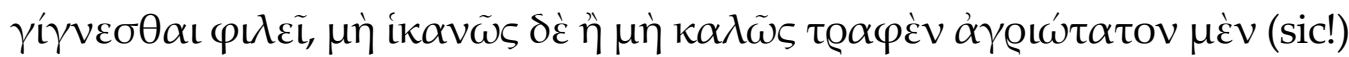

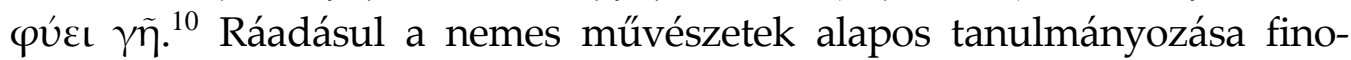
mabbá teszi az erkölcsöket, s nem hagyja, hogy vadak legyenek. ${ }^{11}$

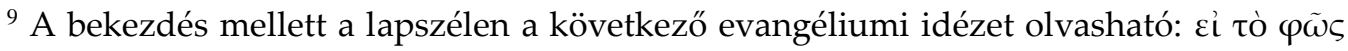

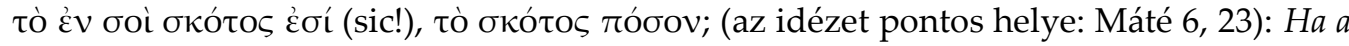
világosság, amely benned van, sötétség, mekkora lesz maga a sötétség? BIBLIA (1987: 1102).

${ }^{10}$ Plat. Leg. 6, 766a: Az emberröl azt szoktuk mondani, hogy szelíd, de csak ha szerencsés természet és helyes nevelés párosulnak nála, akkor szokott a legszelídebb és legistenibb élölénnyé válni; ha ellenben nem eléggé vagy nem jól nevelik, a legvadabb minden élólény között, ahányat csak szül a föld. Kövendi Dénes fordítása: PLATóN (1984: 681-682).

${ }^{11}$ Ov. Pont. 2, 9, 47sk. Van Schurman az idézett disztichont folyó szövegben, az idézés jelzése nélkül közli. Magyar verses fordítása: Tedd hozzá, hogy a szépmúvészet, hogyha tanuljuk, / ősi szokást szelidit, tiltja az öldökölést. Kartal Zsuzsa fordítása: OvIDIUS (1991: 6).
} 
Végül a tudatlanság veszélye megmutatkozik a bünre tekintve magának a bűnnek és erénynek a természetéből. Mivel ugyanis az erény minden cselekedetéhez akkora ḋk@í $\beta \varepsilon \iota \alpha$ (olvasd: akribeia = pontosság) kívántatik meg, hogy annak teljes egészében meg kell felelnie a helyes gondolkodás szabályának, a bünnel teli gondolkodáshoz akár a legcsekélyebb $\alpha \tau \alpha \xi \hat{\imath} \alpha$ (olvasd: ataxia = rendetlenség) is elegendő, pedig ez természetes velejárója a tudatlanságnak.

A bizonyító helyeket és példákat itt a rövidség végett mellőzöm.

\section{AZ ELLENFELEK CÁFOLATA}

A következő előfeltételeket előre kell bocsátanunk.

Először is akadnak ellenfeleink között, akiket valamilyen elöítéletek vakítanak el, és nem korlátozzák le alanyunkat, hanem úgy gondolják, hogy tételünkből következik, hogy sem a körülményeket, sem a tehetséget nem kell figyelembe venni, és ezáltal az állítmány kevésbé illeszkedik hozzá.

Azonkívül olyanok is vannak, akik vagy a hasznon vagy a hiú dicsőségen kívül - úgy látszik - semmi mást nem ismernek el a tanulmányok céljának, hacsak nem szolgálnak közösségi kötelezettségeket, már-

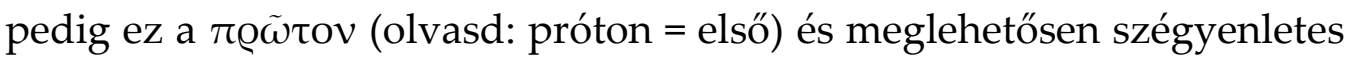
$\psi \varepsilon \tilde{v} \delta o \varsigma$ (olvasd: pseudos = hazugság, csalás), mintha éppenséggel fölös-

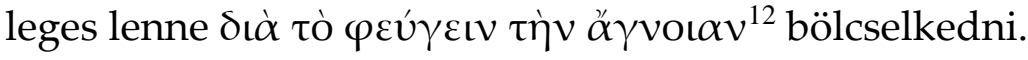

Végül vannak olyanok, akik nem mondják, hogy a tanulmányok általában nem illenek a nőkhöz, hanem csak azt, hogy a magasabb szintü tudomány. Öket éppenséggel a féltékenység gyötri, vagy éppen a féle-

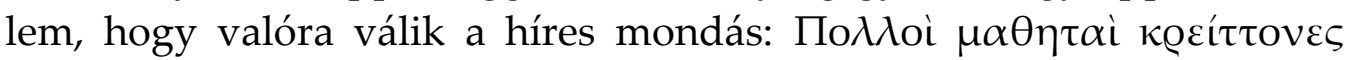
$\delta \iota \delta \alpha \sigma \kappa \alpha ́ \alpha \omega \nu{ }^{13}$ Vagy egy másik mondás a réges-régi költőtől:

Ti, ifjakul, asszonyi szivvel birtok, férfiéval ama szüz. ${ }^{14}$

\footnotetext{
${ }^{12}$ A lapszélen a hely megadása: Arisztotelész Metafizika 1. könyv, 2. fejezet. Modern hivatkozási elvek szerinti pontos hely: Arist. Metaph. 1, 982b. Magyar fordítása: hogy a tudatlanságból kiszabaduljon. Halasy-Nagy József fordítása: ARISZTOTELÉSZ (2002: 41).

13 Magyarul: Sok tanítvány meghaladja mesterét. Menandros Sententiae e codicibus Byzantinis 651.

${ }^{14}$ Szalay László fordítása: CICERO (1857: 28). Enniusnak tulajdonított idézet Cicerónál: Cic. Off. 1, 61. Vos etenim juvenes animos geritis muliebres, I Illa virago viri.
} 


\section{Az ellenfelek tétele}

A tudomány müvelése nem illik a keresztény nőhöz, hacsak nem valami isteni indíttatás vagy ihlet ösztönzi erre.

\section{Az alanyból kiinduló érvelés.}

Akinek szellemi képességei gyengébbek, annak nem való a tudomány tanulmányozása. Márpedig a nők szellemi képességei gyengébbek, tehát:

A nagyobbikat úgy fogják bizonyítani, hogy ha nem akarunk hiába

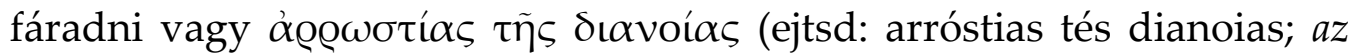
értelem gyengesége miatt) veszélybe kerülni, a tudományos tevékenységhez szilárd és erős szellemi képességek kellenek. A kisebbiket mindenki által elismert igazságként fogják beállítani.

Válaszunk a nagyobbikra: megszorításunk kivételnek tekintette azokat a nőket, akik szellemi képességeik gyengébb mivolta miatt a tudományra mindenestül alkalmatlanok, viszont állítottuk, hogy legalább átlagos képességek szükségesek. Utána azt állítjuk, hogy nem kellenek mindig föltétlenül kivételes szellemek a tudomány müveléséhez: a tények azt bizonyítják, hogy a tudósok mindenütt az átlagos képességűek közül kerülnek ki.

A kisebbikre a válaszom a következő: nem igaz általánosságban, csak a férfi nemmel összehasonlítva. Mert ha a nők szellemi képességei

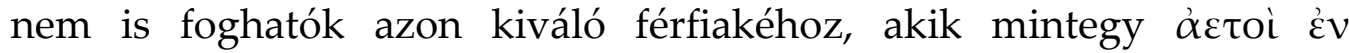

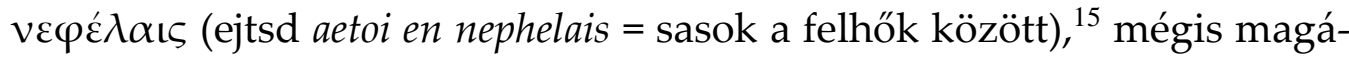
ért beszél az a tény, hogy nem kevés olyan nőt is találni, akit haszonnal lehet tudományra adni. De még az ellentéte alapján is érvelhetünk.

Leginkább annak való a tudományos tevékenység, akinek szellemi képességei nem oly kiemelkedőek. Márpedig a nők szellemi képességei kevésbé kiemelkedőek, tehát:

A nagyobbikat azzal bizonyítjuk, hogy akivel fukarabbul bánt a természet, annak valók leginkább azok a közhasználatú segédeszközök,

\footnotetext{
${ }^{15}$ A kifejezés változatai görög irodalomban többször is előfordul, például: $\alpha \varepsilon \tau o ́ v ~ \tau \varepsilon \varepsilon \dot{\varepsilon} v$

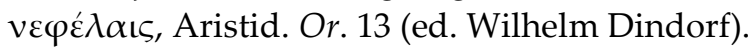


melyekkel orvosolni lehet e fogyatékosságot. Márpedig a tudományos tevékenység ilyen közhasználatú segédeszköz, tehát:

II. Ellenvetés

A tudományos tevékenység azoknak való, akiknek lelke nem hajlik a tudományos tevékenységre. Márpedig a nők lelke nem hajlik a tudományos tevékenységre, tehát:

A nagyobbik bizonyítéka az, hogy nem tehetjük, ami - mint mondják - Minerva ellenére van.

A kisebbiket a gyakorlat bizonyítja: nők igen ritkán adják a fejüket a tudomány müvelésére.

A nagyobbikra a válaszunk, hogy azt kellett volna mondani, hogy akinek a lelke minden eszköz kellő mértékű bevetése ellenére sem hajlik a tudományos tevékenységre, annak nem való a tudományos tevékenység, máskülönben a következmény téves.

A kisebbikre azt mondjuk, hogy senki sem ítélheti meg helyesen tudomány iránti hajlandóságunkat, míg nem ösztönzött bennünket a legjobb módokon és eszközökkel, hogy tudománnyal foglalkozzunk, s egyszersmind ne adna valamelyes ízelítőt édességük ízéből. Habár számos példa mutatja, hogy az ellenkező állítás igaz.

\section{Ellenvetés}

Akit cserbenhagynak a tudomány műveléséhez szükséges eszközök, annak nem való a tudomány múvelése, márpedig a nőket cserbenhagyják a tudomány müveléséhez szükséges eszközök, tehát:

A nagyobbik vitán fölül áll. A kisebbiket úgy próbálják igazolni, hogy manapság nincsenek olyan akadémiák és kollégiumok, ahol gyakorolhatnák magukat. De ezt a következtetést cáfoljuk, mivel elegendő, hogy a szülők vagy egy magántanár felügyelete alatt otthon gyakorolják magukat.

\section{Ellenvetés}

Akiknek tanulmányai jellemzően céltalanok, azoknak kevéssé valók a tanulmányok. Márpedig a nők tanulmányai jellemzően céltalanok, tehát:

A nagyobbik igazolható, mivel minden valami cél érdekében történik. A kisebbiket azzal igazolják, hogy [a nők] csak nagyon ritkán vagy 
éppen sohasem jutnak közéleti politikai, egyházi, akadémiai stb. tisztségekhez. Válaszunk a nagyobbikra úgy szól, hogy a nők az elméleti tudományok célját mindenképp beteljesítik, a gyakorlatiakban pedig (amint azt az imént említettünk) ha nem is teljesítik be azok elsődleges vagy közéleti célját, a - hogy úgy mondjam - másodlagos, jellemzően magánéleti célját azonban beteljesítik.

\section{Ellenvetés}

Akinek csekély tudás is elég hivatásának beteljesítéséhez, ahhoz nem

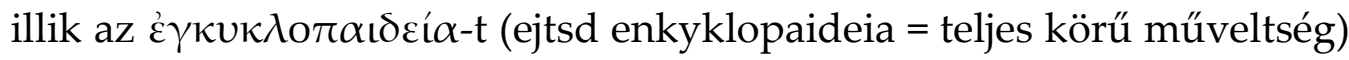
sem pedig a tudomány magasabb foka, márpedig a nőknek hivatásuk beteljesítéséhez csekély tudás is elegendő, tehát:

A nagyobbik érv következményét a következőképpen igazolják: mivel felesleges vagy hivatásától eltérő dolgokat müvelni senkinek sem illik. A kisebbiket a következőképpen fogják igazolni: mivel tudnivaló, hogy a nők hivatásának határai meglehetősen szük területet foglalnak magukba - ezek magától értetődően a magán-, illetve a gazdasági élet határai.

A nagyobbik figyelmen kívül hagyásával a kisebbikre a következő választ adjuk: az állítás szavai kétértelmüek, először is a hivatás (vocatio) szó. Ugyanis ha ezen a magánéletre való elhivatást értik szemben a közéleti szerepvállalással, ugyanezen gondolatmenet alapján azt is mond-

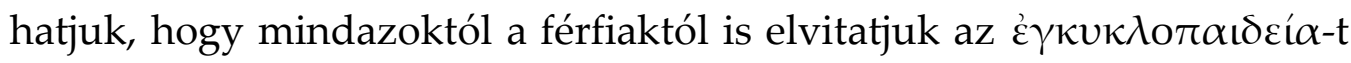
(ejtsd enkyklopaideia = teljes körü müveltség) vagy akár a tudomány magasabb fokát is, akik csak magánéletet élnek. Plutarchos véleménye mégis megfontolásra érdemes, minden egyes emberről, lett légyen bár-

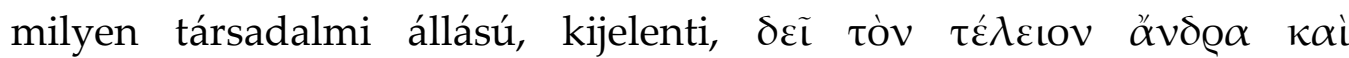

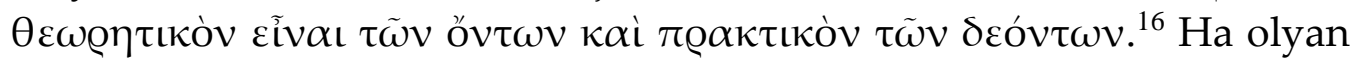
különleges elhivatásnak értik, ami a családfenntartásra vagy gazdasági tevékenységre irányul, akkor kijelentjük, hogy ez ama általános hivatást, mely - akár keresztények, akár csak emberi lények vagyunk - mindenkit egyaránt illet, semmiképp sem zárja ki. Sőt merem állítani, ez utóbbira leginkább egy hajadonnak lehet, és kell is, hogy legyen érkezése,

\footnotetext{
${ }^{16}$ [Plut.] Placita phil. (874d-911c): A tökéletes férfinek szemlélődönek kell lennie az adott helyzettel, és cselekvőnek a szükségletekkel kapcsolatban.
} 
amennyiben az előbb említett okozta akadályoktól ő mentes a lehető

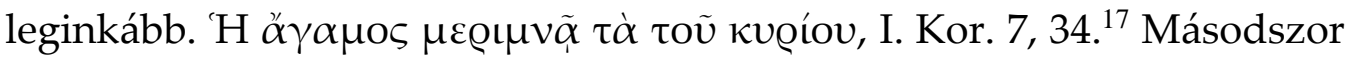
kétértelműség van az „elég” szóban - ennek kiküszöbölésére megfelel, amit fentebb az „illik-e” kifejezés meghatározásánál a tudomány tanulmányozásának szükségességéről mondottunk.

A tételünk tehát érvényes:

A keresztény nőhöz illik a tudomány tanulmányozása.

Ebböl kiindulva a következő összefoglaló következtetésre juthatunk:

A legjobb és igazolt érvek, a bölcsek tanúságai és végül kiváló nők példái alapján is a nőknek neki lehet és neki is kell buzdulniuk, hogy efféle életet válasszanak, elsősorban pedig azok, akik erre idejük van, valamint nőtársaiknak jobban el vannak látva segédeszközökkel a tudomány tanulmányozására. És mivel nagyszerű már gyermekkorunktól kezdve nemes tudományokba merülni, ezért úgy vélem, elsősorban éppen a szülőket kell erre ösztönözni s kötelességükre komolyan figyelmeztetni.

\section{Felhasznált irodalom}

ARISZTOTELÉSZ 2002 ARISZTOTELÉSZ: Metafizika. Fordította, bevezetéssel és magyarázatokkal ellátta Halasy-Nagy József, Szeged, 2002.

BIBLIA 1987

CiCERO 1857

BiBLIA. Ószövetségi és újszövetségi Szentírás. Ötödik kiadás. Budapest, 1987.

OvIDIUS 1991

Marcus Tullius CiCERO A kötelességekről magyarul Szalay László által, Pest, 1857.

OvIDIUS 1991

Publius Ovidius Naso: Levelek Pontusból. Fordította, az utószót és a jegyzeteket írta Kartal Zsuzsa, Budapest, 1991.

OVIDIUS 1975

Publius Ovidius Naso: Átváltozások (Metamorphoses). Fordította Devecseri Gábor, Budapest, 1975.

PLATÓN 1984

PLATóN összes múvei. Harmadik kötet, Budapest, 1984. [Törvények: Kövendi Dénes fordítása]

17 A nem házas asszony [...] arra gondol, ami az Úré. Ford. Dr. Gál Ferenc: BIBLIA (1987: 1313). 